\title{
Circulation of the late Elizabethan and Early Stuart Epigram
}

JAMES DOELMAN

Alors que l'épigramme en tant que genre littéraire puise à des sources chirographiques, sa brièveté propre à sa pratique à la Renaissance, a souvent entraîné un glissement vers une diffusion orale, manuscrite et imprimée. À cette même époque, l'épigramme était marquée par une tension entre l'inspiration de son origine littéraire classique et ses contenus domestiques et souvent vulgaires. Certains épigrammistes des plus ambitieux, tels que John Harington, John Owen et Ben Jonson, ont tenté de contrôler la circulation de leurs ouvres, et de se présenter comme des auteurs du même type que Martial. Ils ont résisté au mode plus libre de la diffusion orale, et ont davantage estimé la plus grande stabilité du livre imprimé comme médium, ce dernier semblant promettre à leurs poèmes, éphémères individuellement, une durable réputation littéraire. Néanmoins, leurs épigrammes font parfois preuve d'une influence de la tradition de la plaisanterie vulgaire. Le mode de diffusion des épigrammes politiques et prophétiques est par ailleurs assez différent. Ils se développent surtout oralement en raison de leur contenu controversé, sans identification d'auteur, et considéré plutôt comme " ce que toute personne dirait ».

7 he epigram as a genre defies the most frequent pattern of literary forms, 1 that is, an historical movement from oral to written modes. Instead, the epigram developed from the chirographic form of the classical epitaph, which consisted of short verses literally inscribed upon a tombstone. Throughout its history the epitaph offered the possibility of enduring remembrance of the deceased, as the engraved poetic lines promised to be as long-lasting and unchanging as the stone itself. From there the broader genre of the non-funerary epigram developed, best known as practised in the Greek Anthology and by the Latin poet Martial, and in these as well the written mode dominated. ${ }^{1}$ Thus, 
the classical legacy of the epigram offered a fixed, written form as the norm, one that the more ambitious epigrammatists of the Renaissance attempted to follow. However, in practice, the Martialian epigram existed in tension with both the anonymous political distich, and what might be called the "common epigram," which derived from the tradition of vernacular distichs and jests. There was also frequent slippage of the epigram between oral and written circulation, a pattern similar to that which Adam Fox has demonstrated in a wide range of literary forms. ${ }^{2}$ This was partially reflective of a continuing tension between the ephemeral and the long-lasting within the epigram genre itself: was the epigram enduring or disposable? ${ }^{3}$ Political circumstances, the competing tradition of the common epigram, and the distinctive brevity of the genre, all contributed to create overlapping oral, manuscript, and print cultures of the epigram.

Simple binaries of print versus manuscript, or written versus oral, are insufficient to describe the epigram in this period: the varieties of media within these categories need to be considered. As H.R. Woudhuysen has shown, there was a wide range of manuscript types in the period: authors' manuscripts, presentation or gift manuscripts, and miscellanies among others. ${ }^{4}$ Charcoal upon a wall (the "fools paper") or hastily penned lines pinned up in a tavern carry very different cultural weight than a gift manuscript of epigrams penned by a writing master with calligraphic skills. Jonson's carefully printed epigrams in the 1616 Folio stand in striking contrast to the casual printings of Henry Fitzgeffrey's or John Cooke's epigrams. ${ }^{5}$ And in the oral realm, much depended upon the social circles within which the verses were uttered.

What is striking about the Renaissance epigram is the way in which it spilled over social and intellectual boundaries, managing to be both a highly self-conscious form in imitation of the classics, and a vernacular, popular form that circulated among the widest publics. This tension between the various traditions of the epigram was never fully resolved, and throughout the period it was bound up with the question of modes of circulation. The common epigram made wide use of all three modes, frequently shifting between them and reaching wide audiences. This freewheeling circulation is reflected in Puttenham's description in The Arte of English Poesie:

this Epigramme is but an inscription or writting made as it were upon a table, or in a windowe, or upon the wall or mantell of a chimney in some place of common resort, where it was allowed every man might come, or be sitting to chat and prate, as now in our tavernes and common tabling houses, where many merry heades meete, and scrible with ynke with chalke, or with a cole such matters as they would every ma[n] should know, \& descant upo[n]. Afterward the same came to be put in paper and in bookes, and 
used as ordinarie missives, some of frendship, some of defiaunce, or as other messages of mirth. ${ }^{6}$

This definition would not only fit the anonymous manuscript distich, but also the printed epigrams of John Heywood, the most prolific and popular of English epigrammatists of the mid-sixteenth century, whose poems were frequently "printed separately on flyleaves or broadsides,"7 that is, as separate sheets suitable for public posting. Like lines scrawled on a wall, or words “on everyman's lips," these printed epigrams were offered to all who might read—or be read to. In contrast, the Martialian epigrammatists of the 1590s through the 1630s (Sir John Harington, Jonson, and John Owen, for example) attempted to control and limit the readership of their works, and insisted that their lines had an individual source rather than being what "all men might say.” They resisted oral circulation and favoured gift manuscripts and sometimes large print publications that would strongly link the epigrams with their authorship.

While such conflicts over circulation occurred with many poetic forms, the brevity of the epigram complicated the situation by making oral circulation more likely, and this was threatening to authors, as it was likely to bring about changes or to render a poem anonymous or pseudonymous. Manley has demonstrated the tendency of epigrams to label and fix the identities of their subjects, ${ }^{8}$ and unauthorized oral circulation threatened this fixedness. Epigram books themselves provide evidence of resistance to the oral circulation of their contents, and the desire to keep their work distinct from such predominantly oral forms as the jest, the proverbial couplet, and the libellous political distich.

However, once released, whether through private gift manuscripts or printed books, even these Martialian epigrams did take on an oral dimension. Like so many books of the time, they were often read aloud to an audience, either by the poet himself or by another. ${ }^{9}$ Individual epigrams at times acknowledge this listening audience. John Harington, whose epigrams provide the most evidence of real and anticipated audiences, notes that "The Readers, and the Hearers like my bookes." ${ }^{10}$ Harington, who never printed collections of his epigrams but offered gift manuscripts of selections to various figures, including Lady Rogers (his mother-in-law) and King James, also comments on how his epigrams are performed orally by others. He complains that Sextus "doost read so harsh, point so perverse,/It [the epigram] seemed now neither witty nor a verse."11 In contrast, Harington praises Queen Elizabeth’s oral performance of his poems: "[You] so pronounst each word, and every letter/Your gracious reading grac’t my verse the better." ${ }^{2}$ However, once 
epigrams such as these were heard in public settings, they might be used by others, and, like Martial, Harington complains of a reader who has made a practice of memorizing Harington's verses to perform as his own, a transference into the oral realm which masks authorship. ${ }^{13}$ Similarly, Jonson complains of "Playwright," who "hearing some toys I'd writ," stole five of them for use in a play. ${ }^{14}$ These poets were struggling against the general tendency in oral or manuscript culture for collectors to make the poems they heard or read their own.

Harington and Jonson were attempting to control circulation in the face of a strong tradition of widespread mixed transmission of politically charged epigrams. These poems had a life of their own in the public forum: they were exchanged at the prime newsgathering points (such as St. Paul's, the Royal Exchange, Pissing Conduit, and the Temple Cloisters), and found their way into newsletters and eventually miscellanies of verse kept by individuals. Our evidence of course is now in manuscript - most often embedded (or attached) epigrams in newsletters - but these repeatedly point toward at least partially oral circulation. In his letters John Chamberlain frequently notes that a certain poem is "being whispered" or refers to the "buzz" of scandalous lines: both terms suggest oral transmission.

This oral transmission might easily lead to further written copies, frequently with significant variations as the gist or basic structure of the epigram rather than its exact word order is remembered. (Woudhuysen has noted the extent to which surviving manuscript miscellanies may preserve corruption due to "the compiler's difficulties in remembering what he read or heard, whether it was sung or spoken."15) In English epigrams it is most frequently the rhyme words that are preserved, and thus recurring epigrams cannot always be identified in first-line indices. The flexibility of Latin word order also allowed for wide variation. This is especially clear in the case of Andrew Melville's famous Latin epigram on Sir William Seymour's imprisonment in the Tower for his secret marriage to Arabella Stuart in 1610 (Melville had been imprisoned for his mocking of the ornaments upon the altar at the Royal Chapel):

Communis tecum mihi causa est carceris, Arabella tibi causa est; Araque sacra mihi. ${ }^{16}$

[The cause of your imprisonment and mine is the same: a beautiful "Ara" is the cause of yours, a sacred “Ara” (altar) the cause of mine]

Melville sent these lines to Seymour, and they also circulated widely at court in a variety of forms, all with the same basic sense, but different word order. For example, one manuscript has "Causa mihi tecum communis carceris, 
Ara/Regia, bella tibi, Regia sacra, mihi,"17 a word order that simply cannot be attributed to scribal error, but must reflect oral circulation. ${ }^{18}$

A supreme example of the complexity of mingled written and oral epigram circulation in the period is found in a letter of Joseph Mead from the winter of 1622-23. He describes an entertainment at Cambridge where "Dr. Richardson [probably John Richardson, Master of Trinity College] brought before the king a paper of verses, in manner of an epigram, which Bishop Neil read, and others. A friend of mine, over the bishop's shoulder, got two of them by heart." 19 Once again we have a mixed transmission: the lines (which may have been orally circulating before their presentation in written form to the king) have now entered into something once again closer to an unstable oral form. This example illustrates how easily the details of an epigram might have become bungled or changed as they were indirectly obtained. The episode also has an illicit air to it: that which was circulating among the most elite group now has been surreptitiously obtained and will likely spread among a broader, more common audience. Lines circulating in this fashion are subject to "a scholar's fickle memory," as Joseph Mead puts it in one of his letters, as he passes along a distich he knows is metrically deficient. ${ }^{20}$

It would be best to assume that most political epigrams of the period went through an initial period of mixed transmission, during which they were both written down and posted, and then also remembered and passed along by word of mouth, perhaps once again to be written down. This intense and widespread early transmission of varying types would ultimately be replaced by a more static transmission as the epigrams found their way into more permanent collections such as commonplace books. Circulation did not stop at that point, as Marotti has demonstrated how commonplace books were borrowed and selectively copied. Some epigrams might be revived to a second period of intense circulation by word of mouth and on single sheets as the topic became one of intense public interest again. When such epigrams once again seemed relevant, they in turn provoked new response epigrams on the same subject. ${ }^{21}$ For example, Andrew Melville's lines on the royal altar (“Cur stant clausi Anglis libri duo Regia in Ara?”) were resurrected (and responded to) repeatedly through the century as the liturgical debate flared up. As late as the 1660 s fresh epigrams were being written against his. ${ }^{22}$

A well-known prophetic distich of the early 1600s that expressed hope for further reformation under Prince Henry shows some of the dynamics at work:

Henry the 8. pulld down abbeys and cells, But Henry the 9. shall pull down Bishops and bells. 
Harington offers this account of one stage of its circulation:

About the monthe of August last past, [A.D. 1606] his Majestie then being at Windsor, a Londoner of honest credit told me how a preacher in the citty had, with more zeale than discretion, (reprehending the spoylers of the Church, and such as gape for such spoyls) told withall how some lewd person had scatterd in divers places this ryme:... ${ }^{23}$

Thus, in attempting to refute the "spoylers," a zealous preacher had inadvertently heightened the buzz about the lines, as the "vulgar auditors" found the memorable distich far easier to carry away than any sermon. Hence, a "scatterd" written rhyme had achieved a new circulation, one that was ironically increased and made permanent by Harington's own work.

In political distichs the title or "lemma" was of great importance, for often it offered the only identification of the subject. Frequently, in oral or manuscript circulation of the moment this context might be assumed or provided by oral preamble rather than explicitly stated. Or, to convey the epigram in a titleless form might render the lines safe and general. Clearly libellous epigrams would be more likely simply heard and remembered, for to carry a copy of such on one's person would be dangerous. If we take the letters of John Chamberlain as fixing in written form the usual ways of spreading epigrams orally, there is generally a lead-up to the libel or distich itself, as the contemporary situation is described. He notes, for example, the success of Christopher Villiers in attaining a position in the king's bedchamber, and then adds that certain libels are floating about and quotes one as an example:

some riming companions do not forbeare to taxe him for yt, as one by way of a prognostication sayes

Above in the skies shall Gemini rise, And Twins the court shall pester, George shall call up his brother Jacke And Jacke his brother Kester.

with more of like stampe. ${ }^{24}$

An epigram might begin as a very local and elite phenomenon, limited to a courtly circle, or the Inns of Court, but frequently the lines eventually spread much further. In Jonson's Poetaster, a play heavily involved in the question of defamation by libel, Captain Tucca complains of how a libelous epigram 
lives eternally to upbraid him [the defamed] in the mouth of every slave tankard-bearer or water-man; not a bawd or a boy that comes from the bake-house but shall point at him. ${ }^{25}$

This seems to illustrate what Fox has suggested about libels generally: once composed and let loose into the public domain, in oral form they could reach a very wide audience, repeated by servants, apprentices, and watermen. ${ }^{26}$

Composers of such verses might desire anonymity to avoid prosecution for libel, but I would suggest that the authorless nature of these politically charged lines can be a reflection of the perceived communal nature of the verses. It is not so much that a name was suppressed, but that the unascribed nature of the epigram was essential to the form, that these were the "common" thoughts - what was on everyone's lips — and that there was not a significant difference in the period between the first and subsequent utterers of such lines. Even the frequent phrasing "who first sung it" suggests that the epigram is common (as well as oral) property, and certainly the authorities saw possession or utterance of a libellous epigram to be criminal regardless of who the author might have been. This common approach is consistent with the epigram's roots; as Gutzwiller notes, "the authorial disengagement later associated with epigrammatic style is....an inheritance from the traditional objectivity of earlier inscribed verse."27 Detachment in the epigram was sometimes a vehicle for an urbane and even cynical voice, but in the most widely circulated epigrams its more important function was that of a supposed universality.

An epigram that circulated without a clearly identified author became "filius populi," a bastard belonging to everyone and no one. The address "To the Courteous Reader" in Cures for the Itch (1626), Henry Parrot's final volume of epigrams, refers to his writing of them, but then in "To the Criticke-seeming Censurer," he presents the "brood" of epigrams as bastards or orphans, "so farre unlikely will it be (I know) to finde the owners or fathers [of these epigrams] out, who questionlesse will quite disclaim them to be their Bastards though nere so jumpe a like in qualities as can or may be possibly required." 28 This seems to be referring to authorship, using the common trope of the poet as the father of the poem. ${ }^{29}$ The game that Parrot invites his reader to join in is two-fold: the usual one of discerning the real subject behind the fictional figures of the epigram, and here the additional game of determining the author. The implications are significant: a poem without a publicly recognized "father," like a literal bastard, came to belong to the people-it was in legal terminology "filius populi." Thomas Heywood refers to a work without an acknowledged author as "filius populi, a bastard without a father to acknowledge", 30 and Parrot suggests that such poems 
might "desperately lye upon the parish for want of shelter." 31 His point here is an important one: an epigram whose author would not claim it became public property and could be collected and reproduced by collectors such as himself. Where authorship of these political distichs was ascribed, it was usually to figures fairly close to the centres of power (although many ascriptions are open to question) and this illustrious authorship was part of the meaning and cachet of the lines. Examples of such "illustrious authors" would include Melville and John Hoskins, well-known for his Parliamentary role.

Like political epigrams, proverbial and jest epigrams tended to circulate in a range of modes and frequently without authorial identification. Manley has explored the overlapping boundaries of epigrams and proverbs: in the educational process both were valued for their summarizing of established wisdom. ${ }^{32}$ At the same time, they differed in their origins: the proverb ostensibly emerged from the oral folk tradition, and the epigram from a chirographic and more literary one. ${ }^{33}$ However, Manley helpfully illustrates how epigrams at times borrowed from and responded to the proverb tradition, adapting its rhetorical techniques and making explicit and specific its metaphoric generalities. ${ }^{34}$ John Heywood's epigrams, first published in 1550, show the coming together of the proverb and epigram traditions. Other epigrams, inspired by the tradition established by John Heywood, reflect affinities with the widespread oral form of the proverb. Adam Fox has shown how the jest tradition mingled oral and written modes: what began as anecdotal conversation came to be written down for future use by individuals, and offered as collections by printers. From both these written forms, further oral use sometimes came. ${ }^{35}$ All three then, the political distich, the proverb, and the jest, established a pattern of mixed and freewheeling circulation.

J.P. Sullivan has suggested that ultimately the English epigram was a melding of two traditions: "There was a native Anglo-Saxon tradition of brief poems incorporating satire, realism and humour, which tended to rely on subliterary farce, proverbs and folk anecdote. The thinking was simple and direct, but early Elizabethan writing was expansive and rambunctious. The classical formalism of Martial pared down this expansiveness."36 It was this melding that threatened those poets set on being Martialian epigrammatists. If, as Manley suggests, "it was the destiny of the genre [of epigrams] to wind up in the hands of hacks," and ultimately become a disposable genre, ${ }^{37}$ the self-conscious English heirs of Martial would not let it do so without a fight. Their emphatic authorship reflects a desire for the enduring status of their work. Martial himself had engaged in just such a struggle, showing a high level of concern over the circulation of his poems, and a sensitive consciousness of the reception of his work. He often reflects on who is reading his 
epigrams, in what context, and also what is being done with them. Martial passed along epigrams, either singly or in books, to friends before publication, and he shows a willingness for them to be performed orally-within certain limits. Thus, he celebrates that his friend Rufus would quote his poems (6:85), and delights that all the people of Rome are singing them (6:60); however, that Celer recites them draws his censure:

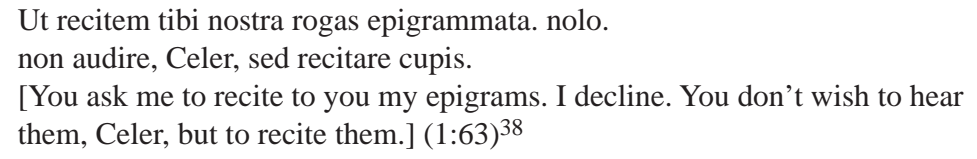

The distinction seems to be that Celer obliterates Martial as poet, making the epigrams fully his own. Martial's epigrams manifest a continuing tension: he moved beyond coterie circulation to a fully published form and yet still wished to maintain control over what was done with his epigrams.

This self-conscious concern on Martial's part was to be echoed by many of his late Elizabethan and early Stuart heirs, such as Thomas Campion, Charles Fitzgeffry, and John Owen among Latin poets, and Sir John Davies, Thomas Bastard, Everard Guilpin, Sir John Harington, John Weever, and Ben Jonson among English ones. To varying extents, these all manifest "emphatic authorship," or "possessive authorship” as Loewenstein calls it, and to maintain their role as authors they greatly limited circulation of individual epigrams. Instead they would offer collections or books of disparate epigrams to individual friends and would-be patrons, and then create yet larger volumes for publication. ${ }^{39}$ The printed word, unlike the spoken, offered to these ambitious poets a longer, perhaps even immortal, life:

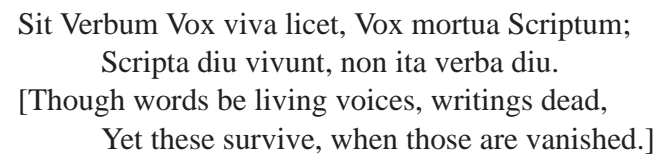

concludes one of Owen's books of epigrams. ${ }^{40}$ The poem enjoys the paradox of the "dead" written form ensuring future life.

While Renaissance epigrammatists might desire a Martial-like reputation, and constantly point to their classical forebear as a model and justification for their art, their epigrams ultimately owed a great deal to the jest and the distich, both of which reached well back into the Middle Ages. ${ }^{41}$ Ben Jonson said of both Harington's and Owen's epigrams that they were mere "narrations," 42 by which he seems to have meant that rather than being brief witty reflections on an individual or situation, they were jest-like in their 
relating of a short tale leading to a final sharp comment. Many epigrams of Harington could best be described as polished jests, many of which are found in printed sixteenth-century published jest books.

Less fastidious than Jonson, Harington quite openly admits these popular sources: one of his epigrams begins, "I heard among some other pretty Tales." 43 He acknowledges that his "matter" is borrowed, but takes pride in what he does with it. In this way he counters accusations of literary theft:

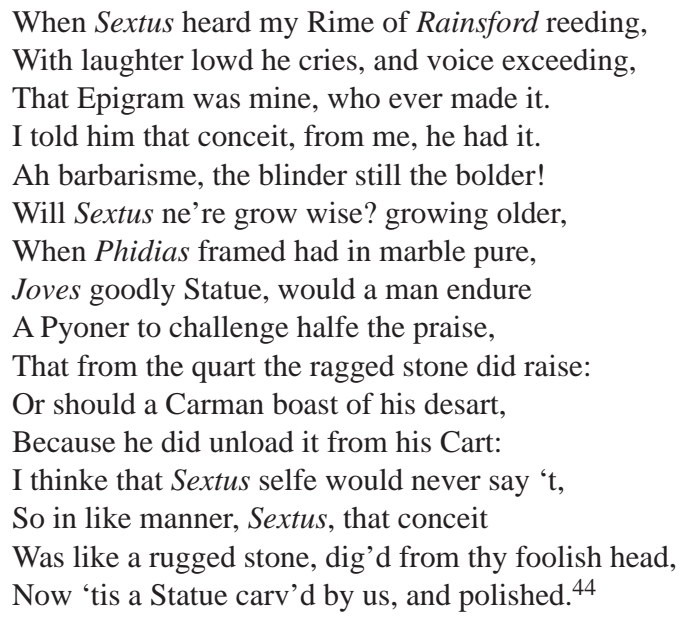

Harington presents himself as the carver and finisher, the one who achieves with the raw material the urbane polish and sharpness that makes it an epigram rather than a mere jest. Harington's prose work, A Supplie or Addicion to Bishop Godwin's Catalogue of Bishops, provides similar evidence of his method: he collected jests by and about churchmen, some of which became the source of epigrams. Thus, he recounts some jests of Bishop Bonner that he had probably received orally: he "having twice lost his bishoprick, walking with his tippet in the strete, one begg'd it of him in scoffe, to lyne a coate; 'No, (sayth he) but thou shalt have a fooles head, to lyne thy cap.' And to another, that bad him 'good morrow bishop quondam;' he straight replyed, 'Farewell, knave semper." 45 These jests of Bonner are reformulated as epigrams by Harington:

Bonner, that late had Bishop beene of London, Was bid by one, Good morrow Bishop quondam: He with with scoffe no whit put out of temper, Reply'd incontinent, Adieu knave semper. Another in such kinde of scoffing speeches, Would beg his tippet, needs, to line his breeches. 
Not so (quoth he) but it may be thy hap, To have a foolish head to line thy cap. ${ }^{46}$

Thomas Bastard acknowledges a similar approach to gathering matter, but also complains of the meagre return for his work:

Reader thou think'st that Epigrams be rife, Because by hundreds they are flocking here. I reade an hundred pamphlets; for my life Could I finde matter for two verses there? Two hundred ballets yeelded me no more, Besides barraine reading and conference. Besides whole legends of the rustie store, Of stories and whole volumes voyde of sense. And yet the Printer thinkes that he shall leese, Which buyes my Epigrams at pence a peece. ${ }^{47}$

While clearly lacking respect for the pamphlets and ballads through which he searches, he nevertheless acknowledges them as sources. At the same time, the printer has insulted him with his low offer. ${ }^{48}$ In an epigram from Affaniae, Charles Fitzgeffry vividly abuses Thomas Bastard's epigrams for this commonness of source materials:

Nam ab omnibus quot uspiam sient

Triviis, plateis, angiportis, angulis,

Converrit et corradit infameis jocos,

Ut ad sepulchra Ruffa de rogis cibos:

Quin et theatra, compita, Lupanaria,

Et cum tabernis carceres tonsoriis

Deciesque viciesque circinat die,

Et quicquid usquequaque pestilentiae est,

Quicquid cicutae, vel venenati salis

Compilat et catillat, haurit et vorat,

Ut in alienos expuat tandem sinus,

Scolopendra ut unco laesa ferro, protenus

Eructat intestina, virus saepia. ${ }^{49}$

[For from all the crossroads, avenues, alleys and streetcorners in the world he sweeps up and scrapes together his infamous jokes, just as Ruffa gets her meals from graveyard tombs. Indeed, ten, twenty times a day he flits through theaters, crossroads, brothels, jails, together with taverns and barbershops, and whatever of pestilence there may be anywhere, whether of hemlock or venomous wit, he gathers and licks up, drinks down and swallows, so he may spew them in other men's laps, as the nereid worm, hurt by a fish-hook, straightway vomits up its guts, its poisonous secretion. $]^{50}$ 
Fitzgeffry's personal animosity leads him to deny any polishing role for Bastard as epigrammatist; instead, his treatment of the crude raw material is a further stage of corrupt recirculation.

The epigrammatist Henry Fitzgeffrey, who never quite decided whether his epigrams were Martialian or common, complains of those who compose verses in this way:

Such as they at Table sit

Each Jest you speake, will to a Metre fit.

And thus your Witt's sell for their private gaine

And bee accounted Poets for their paine. ${ }^{51}$

Most epigrammatists of the period 1590 to 1630 would be open to the charge of at times composing in this way, offering mere narrations, deeply indebted to a common store of anecdotes and jests. Hence, their very chirographic art was in fact often based on long-standing oral traditions. Those epigrammatists like Harington who recognized this tended to defend themselves by arguing that they offered a more polished version of the jest, one worthy of being fixed in written form or print.

All three forms - the proverbial distich, the jest, and the political couplet-were common, that is, they were what "all men might say." Their oral form and wide circulation detached them from any particular author and made them the property of all. And as there was no clear boundary separating these from epigrams in the Martial tradition, there was no escape from the anxiety experienced by such poets as Harington, Owen, and Jonson. Their attempts to distance themselves from the oral dimensions of their genre, in order to enhance their reputation as authors or defend the legitimacy of their work, were never completely successful. For all its chirographic origins, the epigram in practice remained a genre that occupied the overlapping modes of oral, manuscript, and print, and no number of invocations of Martial could change this.

\section{Brescia University College, University of Western Ontario}

Notes

The research for this article was made possible by a grant from the Social Sciences and Humanities Research Council of Canada.

1. See Kathryn J. Gutzwiller, Poetic Garlands: Hellenistic Epigrams in Context (Berkeley: University of California Press, 1998). She notes, "Even if Hellenistic poets sometimes composed for the stone and sometimes recited their epigrams to friends at social gatherings, they were nevertheless self-consciously aware that their epigrams would ultimately reside with other poetry in a written context.” (pp. 5-6). 
James Doelman / Circulation of the late Elizabethan and Early Stuart Epigram /71

2. Adam Fox, Oral and Literate Culture in England, 1500-1700 (Oxford: Clarendon Press, 2000). See also Harold Love's chapter in The Cambridge History of the Book in Britain, vol 4: 1557-1695, ed. John Barnard, D. F. McKenzie, and Maureen Bell (Cambridge: Cambridge University Press, 2002), pp. 97-121.

3. See Lawrence Manley, "Proverbs, Epigrams, and Urbanity in Renaissance London," English Literary Renaissance 15 (1985), p. 275.

4. Henry R. Woudhuysen, Sir Philip Sidney and the Circulation of Manuscripts 1558-1640 (Oxford: Clarendon Press, 1996), pp. 29-203.

5. Henry Fitzgeffrey, Certain elegies, done by sundrie excellent wits : With satyrs and epigrams, (1620); J[ohn] C[ooke], Epigrames. Served out in 52. sverall Dishes for every man to tast without surfeting, (1604).

6. George Puttenham, The Arte of English Poesie, 1589, facs. (Menston: Scolar Press, 1968), pp. 43-4.

7. Robert Bolwell, The Life and Works of John Heywood (New York: AMS, 1966), p. 134.

8. Manley, p. 265.

9. Fox, pp. 36-7. See, for example, Sir John Harington, The Letters and Epigrams of Sir John Harington, ed. Norman Egbert McClure (Philadelphia: University of Pennsylvania Press, 1930), vol. 2, p. 53. Although it was printed, Harington’s Metamorphosis of Ajax may also have been intended for a narrow select audience, whom Harington guided with additional autograph marginalia (Gerard Kilroy, Edmund Campion: Memory and Transcription, [Aldershot: Ashgate, 2005], p. 90).

10. 1:6 (As most Renaissance epigrams were organized into books and numbered, throughout this essay they will be identified by book and epigram number, rather than page or signature). cf. Henry Parrot, “Ad Momum”, Cures for the Itch (1626), sig. F9v.

11. Harington, Letters and Epigrams, 3:6.

12. Harington, Letters and Epigrams, 4:13.

13. Harington, Letters and Epigrams, 2:16. This epigram also appears in Alcilia (1613) [sig. M5v].

14. The Oxford Authors: Ben Jonson, ed. Ian Donaldson (Oxford: Oxford University Press, 1985), Epigram 49.

15. Woudhuysen, p. 160.

16. Dudley Carleton to Sir Thomas Edmondes, 25 July 1610, Court and Times of James the First, ed. Thomas Birch (London: Colburn, 1849), vol. 1, p. 132.

17. Bodl. Ms. Rawl. Poet. 246, fol. 16r. See also Court and Times of James the First, vol. 1, pp. 127 and 132.

18. Raphael Thorius's lines on Ralegh ["Viderat Acephalos"] are another good example of this; see Michael Rudick, ed., The Poems of Sir Walter Ralegh: A Historical Edition (Tempe, Arizona: Renaissance English Text Society, 1999), p. 199.

19. Mead to Stuteville, 15 March 1622/23, Court and Times of James the First, vol. 2, p. 375.

20. Mead to Stuteville, 24 Feb. 1626/7, Court and Times of Charles the First, ed. Thomas Birch (London, 1848), vol. 1, p. 199. 
21. Leicester's Commonwealth, a famous libel of the 1580s, was being read by Anne Clifford in 1619. See Katherine O. Acheson, ed., The Diary of Anne Clifford, 1616-1619 (New York \& London: Garland, 1995), p. 119, 2 Dec., 1619; the work was reprinted in 1641.

22. See my “The Contexts of George Herbert's Musae Responsoriae,” George Herbert Journal 2 (1992), pp. 42-54.

23. A Supplie or Addicion to Bishop Godwin's Catalogue of Bishops, in John Harington, Nugae Antiquae, ed. Henry Harington (1792, Rpt. New York: AMS, 1966), vol. 2, p. 3.

24. Chamberlain to Carleton, 8 Feb. 1616/17, John Chamberlain, Letters, ed. Norman Egbert McClure (Philadelphia: American Philosophical Society, 1939). Most frequently, Chamberlain includes the epigrams themselves on separate sheets; this would allow the reader of the letter to dispose the possibly incriminating evidence after reading it, while saving the letter itself.

25. Ben Jonson, Poetaster, ed. Tom Cain (Manchester: Manchester University Press, 1995), 4.3.111-14.

26. Fox, p. 347.

27. Gutzwiller, pp. 11-12. The Italian Renaissance tradition of pinning political libels upon the statue "Pasquin" reflects a similar distancing of lines from a particular individual.

28. sig. A3v.

29. This language of the fathering of the poems, and fathering a poem upon someone, seems to have been particularly widespread in the 1620s, for example in the public commentary about certain poems circulating under King James’s name.

30. Joseph Loewenstein, Ben Jonson and Possessive Authorship (Cambridge: Cambridge University Press, 2002), p. 50, quoting the prefatory epistle to Heywood's The English Traveller (1633).

31. sig. A3r-v.

32. p. 249.

33. Manley, p. 250.

34. Manley, pp. 256-65.

35. Fox, pp. 39-40.

36. J. P. Sullivan, Martial: The Unexpected Classic. A Literary and Historical Study, (Cambridge: Cambridge University Press, 1991), p. 287.

37. Manley, p. 275.

38. Martial, Epigrams, trans. and ed. Walter C.A. Ker, Loeb Classical Library (Cambridge, Mass.: Harvard University Press, 1947), 1:63.

39. Sir John Harington's use of them as gifts has been most fully explored by Jason ScottWarren, Sir John Harington and the Book as Gift (Oxford: Oxford University Press, 2001). Ann Baynes Coiro notes how "not one of Herrick's brief epigrams appears in a manuscript before the publication of Hesperides, whereas 39 lyric poems, ... appear over and over again." See Coiro's Robert Herrick's Hesperides and the Epigram Book Tradition (Baltimore: Johns Hopkins University Press, 1988), p. 184. 
James Doelman / Circulation of the late Elizabethan and Early Stuart Epigram /73

40. John Owen, Ioannia Audoeni Epigrammatum, ed. John R.C. Martyn. 2 vols. (Leiden: E.J. Brill, 1976), 3:208. Trans. Dana Sutton, "Phililogical Museum,"<http://www. philological.bham.ac.uk/owen/3eng.html.>

41. Sullivan, p. 287.

42. Jonson in "Conversations with Drummond," The Oxford Authors: Ben Jonson, pp. 596 and 600 .

43. Harington, Letters and Epigrams, 1:62.

44. Harington, Letters and Epigrams, "How Sextus laid claime to an Epigram," 2:53.

45. Harington, Nugae Antiquae, vol. 2, p. 33.

46. Harington, Letters and Epigrams, “Two witty answers of Bishop Bonner,” 4:15.

47. Thomas Bastard, Chrestoleros (1598), 6:28.

48. In 2:37, “Ad Guilielmum Sutton,” Bastard notes that he had vowed to write an epigram a day, but "wanted matter and invention."

49. Charles Fitzgeffry, “In Scurram,” in Caroli Fitzgeofridi Affaniae (1601), p. 73.

50. Trans. Dana Sutton, "Philological Museum”, <http://www.philological.bham.ac.uk/ affaniae/2eng.html $>$ ). My identification of this figure as Bastard rests upon a reference earlier in the epigram to someone who mocked Fitzgeffry's one-eyedness. He is addressed as "abiesque septem rabularum," [you frenzy of seven ranters," trans. Sutton]. The likeliest candidate is Thomas Bastard, whose Chrestoleros was in seven books. In his epigram 2:4 he mocks his host who has only one eye.

51. Henry Fitzgeffrey, Certain Elegies (1620), sig. A5v. 